same image, since the original one act as top-down information to recognition. Even if we do not see original image, we can spontaneously recognize hidden objects after seeing for some time. Murata et al., (2005) found that the time to recognize a hidden object follows a rate equation whose formation has remarkable homology to the Arrhenius equation of a chemical reaction. Despite of these behavioral studies, the brain regions involved in top-down processing are still unclear. Here, using fMRI, we investigated the brain regions involved in the recognition process of degraded images. The same degraded images were presented in two blocks between which one block of their original color ones intervened. For the control to the effects of repetitive presentation of the same images, the color images during a half of the intervened blocks were unrelated to the degraded ones. The brain regions activated only when the subjects recognized the hidden objects after the observation of the original color images, were the left inferior frontal gyrus, the left inferior parietal lobule, and the left middle temporal gyrus. The results suggested that the top-down processing for degraded images requires interactive activations among these regions.

\section{P-243 主観色認識における嘎覚刺激の影響}

Olfactory effect in subjective color

Tomoaki Nakamura (1), Yukio-Pegio gunji (2).(1:Graduate School of Science, Kobe Univ; 2:Dept Earth \& Planetary Sci, Kobe univ)

The olfactory system is one of the most primitive sensory systems. A man may feel some basic sensation and atmosphere by using olfactory stimuli. The contex of various cognition and/or perception can be dependent on olfactory stimuli. To estimate contribution of olfaction in perception, we here show the effect of olfaction in subjective color, Fechner color. Fechner color seen in Benham's disk is explained by various theories. The pattern of the disk (white and black area) stimulates cones of retina differently, and it may cause the interaction of nervous cells that generates colors. Another explanation is that different cones have different stay of activation, and the alternation of activation/deactivation sequence can result in colors in brains. It remains that rod also contribute to the Fechner color, and that there are some possibilities of higher order brain function that contribute to Fechner Color. When one sees Benham's disk that rotates very fast it is very hard to see colors. However, some subject report that color is seen in rotating disk. We report how much the olfaction take part in generating subjective color.

\section{P-244 リカレントニューラルネットワークを用いた主観的時間順序再構} 成過程のシュミレーション解析

Simulating the reconfiguration process of subjective temporal order by using recurrent neural networks

Kohei Nakajima (1), Takashi Ikegami (1) (1. Dept General Systems Sciences, Graduate School of Arts and Sciences., Univ of Tokyo)

How the brain orders successive events has been a matter of intense debate in neuroscience. Yamamoto and Kitazawa (Nature Neuroscience, 2001) revealed that subjective temporal order of successive taps to hands, or to the tips of sticks held in each hand, are easily reversed just by crossing the arms. What is astonishing is that especially, in the crossing case, when the tapping interval was less than 0.3 second, mistake rate grew to $100 \%$. This result could be taken as genera functionality of real brain's time-space reconfiguration process. In this session, we try to explain these phenomena and characterize real brain reconfiguration proces of subjective temporal order from dynamical systems perspectives. We prepared the agent containing two arms and corresponding pairs of input nodes, consisted with proprioceptive and exteroceptive inputs, and output nodes to make the agen answer which hands had received the stimuli first. For the agent's internal architectures, we adopted discrete time recurrent neural networks and trained the network by using genetic algorithm depending on the tasks. Preparing the same settings with Yamamoto and Kitazawa's experiment, we evolved the agent's network architectures which can successively determine the order of stimul without crossing the arms by using genetic algorithm. For the experiment, we crossed the agent's arms and analyzed its internal dynamics. Finally, we try to discuss the implication of this model to real brain reconfiguration process of empirical time and space.

\section{$3 \mathrm{P}-245$ 単細胞生物の時間記憶能}

\section{Ability of memorizing time period in the unicellulate}

Tetsu Saigusa (1), Toshiyuki Nakagaki (2), Atushi Tero (2). (1:Dept Tech., Hokkaido Univ; 2 RIES, Hokkaido Univ.)

Unicellular animals might be cleverer than previously thought. Anticipating events are higher functions performed by the brains of higher animals; their evolutionary origins and the way they self- organize, however, remain open questions. Here we show that Physarum polycephalum and Blepharisma japonicum can anticipate the timing of periodic events. The organisms move rapidly under favourable conditions, but stops moving when transferred to less-favourable conditions. They exposed to low-temperature conditions, presented in several times consecutive pulses at constant intervals, reduced thei locomotive speed in response to each episode. When subsequently subjected to favourable conditions, they spontaneously reduced their locomotive speed at the time point when the next unfavourable episode would have occurred. This implied anticipation of impending environmental change. After this behaviour had been evoked several times, the locomotion returned to normal. We explored the mechanisms underlying these behaviours from a dynamical systems perspective. Our results hint at the cellular origins of primitive intelligence and imply that simple dynamics might be sucient to explain its emergence.

\section{P-246 肥満モデルマウスの瞬目反射条件付け学習におけるカンナビノイ ドシステムの関与}

Involvement of brain cannabinoid system to trace eyeblink classical conditioning in diet-induced obese mice.

Takashi Kubota, Yutaka Kirino. Laboratory of Neurobiophysics, Kagawa school of Pharmaceutical Sciences, Tokushima bunri University

Recent reports have suggested that obesity would develop cognitive decline. Cannabinoids have been implicated in both cognitive decline and hyperphagia. In this study, to clarify the role of cannabinoid system in learning deficit elicited by diet-induced obesity, we produced obese mice by feeding high-fat diet for 8 weeks and subjected them to trace version of eyeblink conditioning, in which a shot interval is interposed between the conditioned stimulus and the unconditioned stimulus. Control mice acquired conditioned responses (CRs) by 10 days of trace 500 conditioning and the average of their $C R$ percentage over the last three sessions reached $66.8 \pm 6.5 \%$. In contrast, obese mice exhibited marked lower CRs $(43.4 \pm 6.5 \%)$. Several reports have been indicated that several forebrain structures, including the hippocampus, are required for acquisition of trace CRs, it is possible that these brain structures are impaired in obese mice. In addition, amount of $\mathrm{CB} 1$ receptor expression in the hippocampus was augmented in obese mice ( $162.8 \%$ increase v.s. control mice), whereas there was no change in the cerebellum. These results suggest that obesity-induced impairment of memory acquisition, which was revealed in trace 500 paradigm, may be caused by hyperactivity of endogenous cannabinoid system in the hippocampus. Recent epidemiological study indicated that type 2 diabetes mellitus is a risk factor for Alzheimer's disease. These results may farther suggest that cannabinoid mechanisms underlie both diseases.

\section{P-247 捕食者検知ストレスによる記憶の強化}

Memory enhancement resulting from predator-induced stress

Hiroshi Sunada1), Tetsuro Horikoshi2), and Manabu Sakakibara2)1)Graduate School of Biosci., Tokai Univ., 2)Dept Biol Sci \& Tech., School of High-Tech for Human Welfare, Tokai Univ

The process of memory consolidation following learning is a dynamic process. Thus, it is possible to modulate long-term memory (LTM) formation by stress. We examined at both the behavioral and electrophysiological levels how a predator-induced stress alters LTM formation in the pond snail Lymnaea. We found that training snails in crayfish effluent $(\mathrm{CE}$, crayfish are maintained in an aquarium and water from that aquarium is used) results in a significant enhancement of LTM. That is, in control experiments following a single $0.5 \mathrm{~h}$ training session in pond water (PW) memory persists for only $3 \mathrm{~h}$. If, however, snails are trained in CE memory persists for at least $24 \mathrm{~h}$. In juveniles the data are more dramatic. In PW juveniles do not form LTM, yet if trained in CE they do. Retention tests of adults and juveniles at $24 \mathrm{~h}$ after conditioning are followings:
Adults (PW) $8.43 \pm 0.8 / \mathrm{min}$ (pre)
$7.21 \pm 0.7$ (post); (CE) $9.13 \pm 0.7$ (pre)

$2.78 \pm 0.7 * *$ (post) $(* * \mathrm{p}<0.01)$

Juveniles (PW) $4.56 \pm 0.7$ (pre)

$1.91 \pm 0.4^{* *}$ (post)

The final behavioral test involved one-trial training (1TT). Juveniles do not form LTM following 1TT, yet if trained in CE they do. At he electrophysiological level, we found that training juveniles in $\mathrm{CE}$ alters the synaptic connections formed by a neuron necessary for LTM formation, RPeD1.

We would like to express our gratitude to Prof. Ken Lukowiak (Univ of Calgary) for his collaboration and suggestions to these experiments.

\section{P-248 力学的負荷をかけたときのアリの歩行}

Ant locomotion under the mechanical load

Kazumitsu Hanai(1),Kentaro Ishiura(2), Hiroto Shoii(1), Mamiko Ozaki(2) (1:Dept. Physics, Kyoto Pref. Univ. Med.;2: Dept. Biol., Fac, of Sci., Kobe Univ.

Ants carry a substance of large mass in cooperation with other ants. Even an ant carries a mass of several times larger than its own body weight. We have analyzed the ant movement on the glass dish by examining each position of center of mass from the ant image after taking digital-movie of the walk (30 frames/sec). We have found that the movement of ant is a mixture of short duration of move and rest. The short movements are classified into 3 categories according to their duration, short $(<0.2 \mathrm{sec})$, medium $(0.2<$ duration $<2.1 \mathrm{sec})$, and long $(>2.1 \mathrm{sec})$. We examined the ant walk about 1 hour under the mechanical load to examine the properties of these 3 categories of movements. We used a mass of soldering lead of about the same weight as the body weight, and of about two times heavier than it, stuck on the back of the ant by a quick-drying glue as a mechanial load. When displacements during pre-determined periods are examined, their distribution are different from each other depending on the mechanical loads. Large differences are found in the smaller displacements, but not so much difference in the larger displacements.

\section{P-249 コカイン投与マウスによる歩行メカニズム解析}

The Walking Control in Cocaine-induced Locomotor Activity in Mice

Hiroto Shoji (1), Yasuhito Nakatomi (2), Chihiro Yokoyama (3), Kenji Fukui (2) and Kazumitsu Hanai (1). (1: Dept Physics, Graduate School of Medical Science, Kyoto Prefectural Univ of Medicine. 2. Dept Psychiatry, Graduate School of Medical Science, Kyoto Prefectural Univ of Medicine; 3: Functional Probe Research Lab, Molecular Imaging 